\title{
THE ROLE OF PROFESSIONAL TOURISM ASSOCIATIONS IN LATVIA
}

\author{
Daina Vinklere \\ Turiba University, Latvia
}

\begin{abstract}
After regaining independence in 1991, various sectors of the tourism industry in Latvia are united in professional associations. They represent various stakeholders of the industry in all processes important for tourism development and are part of the tourism management system of Latvia. So far, there has been no specific research conducted on the role of professional tourism organisations in Latvia. Therefore, the aim of this paper is to evaluate the achievements and future prospects of the activities performed by the national level professional tourism associations of Latvia. The empirical part of the research is based on the qualitative research methods - document analysis and structured interviews with board members and members of associations, as well as with a senior official at the Ministry of Economy of the Republic of Latvia. Research results reveal that the role of those organisations in Latvia is valuable and bring about a positive impact on the tourism industry. Despite the variety of opinions, the majority of interviewees believe that in the course of the next 5 years there will be an increasingly strong influence of associations on the development of tourism in Latvia.
\end{abstract}

Keywords: Latvia, NGO, professional tourism associations, tourism management.

\section{Introduction}

After regaining of independence in 1991, tourism management in Latvia was started afresh and along with governmental institutions responsible for tourism, it is also important to create a system ensuring the representation and participation of tourism companies in it. Therefore, with the development of various areas of the tourism industry and the subsequent problematic issues in need for resolution, companies of various sectors united in professional associations. In accordance with Latvian legislation, they were formed as nongovernmental organisations - associations. An association is a voluntary union of persons founded to achieve the goal specified in the articles of association, which shall not have a profit-making nature (Saeima of the Republic of Latvia, 2003). The associations have become defenders of the interests of their sectors, as well as active partners of state and municipal institutions for tourism planning and administration. Despite their sufficiently long period of activities, no summarising, comprehensive studies have been performed on their actions in Latvia. 
Thus, the current study has been carried out with the aim of evaluating the achievements and future prospects of the activities performed by the national level professional tourism associations of Latvia.

\section{Literature review}

Over the past twenty-five years, there has been a growing body of tourism research on stakeholder engagement in successful tourism planning and development. This emphasises the importance of collaboration between stakeholders, due to the composite nature of tourism destinations. UNWTO has identified stakeholders in the tourism industry as tourism professionals, public authorities, professional associations as well as press and other media. Stakeholders in a tourism destination may refer to tourists (as the demand), industries (as the supplier) and hosts (the local community and environment) Sustainable tourism development requires the informed participation of all relevant stakeholders, as well as strong political leadership to ensure wide participation and consensus-building. Stakeholders in sustainable tourism development are divided into three categories: the tourism industry, environmental support and the local community/local government. According to UNWTO the term "stakeholders in tourism development" among others like national and local governments, tourists, etc., includes tourism establishments and enterprises, including their associations. All stakeholders have a different impact and contribution to the development of the tourism industry (UNEP \& UNWTO, 2005). The impact of professional associations and NGO-s frequently play a role, which might otherwise be played by governmental bodies. In some contexts, associations can be seen as part of the public sector while in other instances they are closer to the private sector, and this varies from country to country (Veal, 2010). There are quite many organisations of this type, which are composed of tourism stakeholders. In most cases, such associations are nonprofit organisations. Non-profit organisations are institutions placed between the public and private sectors; they provide services for the public good on condition that they cannot make a profit. Such associations can be local, regional, national or international. Non-profit organisations are also commonly called voluntary associations. The first voluntary tourism associations were created in the nineteenth century in France, Switzerland and Austria with different denominations to dedicate their activity to the promotion of the destination (Candela, 2012). Voluntary organizations include pressure groups, voluntary trusts, some of which have charitable status, and industry associations. They can be further subdivided into those, whose membership is primarily public and those, whose members come largely from within the tourism industry (Mason, 2008). The need for government - business cooperation on tourism 
planning is the equal need for them to cooperate with non-profit organizations as they plan and make decisions on different objects and events (Gunn, 2002).

Despite the fact that there have not been many kinds of research conducted on the role and contribution of professional associations outside Latvia either, several authors have addressed, for instance, the role of Associations of Event Producers in the introduction of new technologies, as well as in promoting sustainable event practice, relationship marketing, membership behaviours in professional associations et al. A number of research initiatives on professional associations have been implemented by Arcodia \& Reid. As a result, the authors have concluded that the exchange of information and the opportunities of members of gaining additional education and training for raising their overall qualification represent the most important mission statement of professional associations. In a different research, the same authors conclude that "the six most commonly occurring categories of services offered by professional associations were educational services, communication, business, community and buying power advocacy services and buying power improvements" (Dickson \& Arcodia, 2010).

Taking into account that the area of tourism is often closely linked with events organisation as well as the fact that in most of the cases the idea behind the creation of professional associations is similar, the operations of the respective associations bare a lot of similarities and can be comparable in terms of research results.

Muzio et al. in their own turn (as cited in Rhodri \& Huw, 2013) have stressed a set of formal qualifications allied to occupation, membership system, legitimacy claims, as well as the shift from national to international orientation as aspects important to professional associations. Those aspects are also topical to the professional tourism associations of Latvia engaged in research of this issue.

\section{Methodology}

Research has been conducted by employing the qualitative research methods - document analysis (web-pages, internal regulations of associations, planning documents) and interviews. Document analysis was mostly based on the information available on the web-pages of associations, which in most of the cases was limited or not unavailable. Therefore, it was possible to collect only a limited scope of information while characterising the activities of the association. 15 structured interviews were conducted involving the board members of 11 associations, 10 interviews with associations members (8 questions) of 7 various associations and 1 representative of a governmental institution (10 questions) - the Ministry of Economy of Latvia, which is directly 
responsible for the development of the tourism industry in Latvia. For the purpose of comparing various opinions of all parties, parts of the questions were similar or identical. The method of content analysis was employed in analysing the interviews. The research was carried out over the period from January to May 2018.

\section{Research Results}

In order to provide a comprehensive overview of the national tourism associations of Latvia, the basic information on the actual operating associations has been summarised in Table 1.

Table 1 The characterisation of the professional tourism associations of Latvia in 2019 (AHRL, ALTA, ALPG, LRTA, LACPM, LMB, LHTC \& LYHA, 2019)

\begin{tabular}{|c|c|}
\hline Name & Characterisation \\
\hline \begin{tabular}{|l|} 
Association of Hotels and \\
Restaurants of Latvia (AHRL)
\end{tabular} & $\begin{array}{l}\text { Founded in 1993, members } 300 \text { accommodation compa- } \\
\text { nies, restaurants, education institutions, service companies; } \\
\text { member of the International Hotel and Restaurant } \\
\text { Association HOTREC }\end{array}$ \\
\hline $\begin{array}{l}\text { Association of Latvian Travel } \\
\text { Agents and Tour operators ( } \\
\text { ALTA) }\end{array}$ & $\begin{array}{l}\text { Founded in 1991, members - } 60 \text { travel agents and tour } \\
\text { operators }+9 \text { associated members; member of the European } \\
\text { Travel Agents` and Tour Operators’ Associations (ECTAA) }\end{array}$ \\
\hline $\begin{array}{l}\text { Latvian Rural Tourism } \\
\text { Association "Lauku ceḷotājs", } \\
\text { (Eng. Rural Traveller) } \\
\end{array}$ & $\begin{array}{l}\text { Founded in 1993, members } \sim 300 \text { rural tourism companies; } \\
\text { member of the European Federation of Rural Tourism } \\
\text { EuroGites }\end{array}$ \\
\hline $\begin{array}{l}\text { Latvian Association of Castles, } \\
\text { Palaces and Manors }\end{array}$ & $\begin{array}{l}\text { Founded in 2000, members - } 105 \text { private or public compa- } \\
\text { nies managing castles, palaces, manor houses for public } \\
\text { access }\end{array}$ \\
\hline \begin{tabular}{|l|} 
Latvian Association of \\
Tourism Information \\
Organisations LATTUR-INFO \\
(LATTURINFO)
\end{tabular} & $\begin{array}{l}\text { Founded in 1996, members - } 46 \text { municipalities and munici- } \\
\text { pal bodies representing tourism information providers and } \\
\text { individuals; member of the European Union of Tourism } \\
\text { Officers (EUTO) from } 2002 \text { till } 2014\end{array}$ \\
\hline $\begin{array}{l}\text { Latvian Restaurant } \\
\text { Association }\end{array}$ & Founded in 2018, members $\sim 60$ restaurants \\
\hline Latvian Museums Association & Founded in 1992, members - 106 museums \\
\hline $\begin{array}{l}\text { Association of Latvian } \\
\text { Professional Guides }\end{array}$ & $\begin{array}{l}\text { Founded in 2002, members- tourist guides; member of the } \\
\text { European Federation of Tourist Guide Associations (FEG). }\end{array}$ \\
\hline $\begin{array}{l}\text { Latvian Tourist Guide } \\
\text { Association }\end{array}$ & Tourist guides \\
\hline Latvian Camping Association & Camping sites \\
\hline Latvia Resort Association & $\begin{array}{l}\text { Founded in 2008, members- } 8 \text { municipalities }+50 \\
\text { associated members or merchants }\end{array}$ \\
\hline $\begin{array}{l}\text { Hostelling Latvia, Latvian } \\
\text { Youth Hostel Association }\end{array}$ & Founded in 2006, members - youth hostels \\
\hline
\end{tabular}


Based on the summarised information, it can be seen that the associations comprise all the major tourism and hospitality companies, the majority of which have been operating already for almost 20 years. Many associations are members of the corresponding international organisations by representing Latvia and by participating in discussions on a range of substantial industry-related decisions in the European Union, as well as in the implementation of various international activities in the field of tourism. In the framework of the national system of tourism administration of Latvia, associations are represented in two consultative councils: The Tourism Committee at the National Economy Council of the Ministry of Economy and the Advisory Council of the Investment and Development Agency of Latvia - the state institutions directly responsible for the development of tourism in Latvia - as well as in various working groups where they substantially implement their objectives and tasks. As depicted in Table 1, there are two organisations representing the industry in some areas, which for a country of the size of Latvia sometimes poses additional challenges.

In order to understand the operational principles of the various associations, the study analysed the objectives and tasks of associations by means of the content analysis method. The objectives and tasks represent the idea and purpose of the association and help to attract members to the association even if few researchers have admitted (Helming, Ingerfurh, \& Pinz, 2013), that publicly communicated goals sometimes may differ from actual ones. The results of this research show that, despite their differences, the objectives of the 11 associations analysed still have one common trait: all of them name the promotion of the tourism industry in Latvia.

Apart from the main objective, associations have also defined tasks, which help to reach their aims. Despite the fact that the tasks are different, some of them are common or similar for all associations. The keywords, which appear in the defined tasks are represented (their area, industry and companies/members) and be the voice, cooperate (they are open to working with others and feel that it can be beneficial for the industry) and promote (members and the tourism industry of Latvia). The fact that some organisations have listed in their tasks to participate in members training, to consult and support enterprises if needed represents another important point. It shows that professional associations pay attention to the level of proficiency and qualification of employees within the industry. The specific activities testifying of the fulfilment of this task have been made available on the web pages of the associations (however, not all of those listed in the research) and have been acquired during interviews. The key educational activities and undertakings for the purpose of raising the qualification of employees involve the development of study and methodological materials, organising of training and seminars, cooperation with education institutions in conducting industry-significant research, guest-lectures 
and participation in state examination commissions in education institutions of various levels engaged in the preparation of tourism industry experts. Representatives of the associations have participated in the development of the respective professional standards of the industry and nominate their representatives for working in the accreditation commissions of tourism and hospitality education programmes.

Other tasks in most cases are specific and related to a particular area, for example: to monitor the supply and demand in the country tourism, etc. Tasks like these help associations to introduce greater clarity in their future plans establishes ways to operate and helps to evaluate their progress.

The interviews with 11 different members of the board of associations (8) established their vision on the role of professional associations, their achievements and challenges facing them. Each interviewee had to answer to 8 previously prepared questions, which were slightly modified according to the situation.

The relationship between professional associations and governmental institutions, combining volunteer work in an association with the main objective and personal life, recruitment of new members, etc., were all named as the main challenges. All interviewees were positive about the issue of cooperation with international organisations seeing a number of benefits, while also mentioning the extra costs this cooperation puts, particularly on smaller associations. The participation in discussions with governmental institutions, working groups, advisory boards and promotion in different media were named as the main activities for representing of professional interests, while less attention is paid to the promotion of the associations themselves in the media. On the issue of activity of members, all interviewees admitted that although membership fees were duly paid, only the smallest part of official members actively engaged in the activities of associations, including with proposing of ideas. Therefore, this issue represents one of the challenges for all associations. Since the assessment of the role of any organisation requires substantial understanding of its achievements, the interviewees named the key achievements of their organisations. They included positive changes in legislation, including taxation policy, cooperation with and respect from governmental institutions, support programmes from the national government and EU projects, successful marketing and travel campaigns/ events, training and various activities targeted at raising the quality of services. Answering the question about the main failure, only a few representatives of associations delivered specific answers and those few spoke about wrong actions, inefficient spending of money and personalities of their leaders. Overall, it seems good but on the other hand, knowing the weak points and failures can help for the development in future. 
10 members of 7 different associations were asked quite similar questions during the interviews. The main findings from these interviews are as follows: Representation of companies and the industry in general and lobbying its interests with governmental institutions were named as substantial factors in defining the role of professional associations. These activities include participation in the development of regulatory acts, support to the activities of companies, "keeping the industry together", exchanges of experience, training, addressing the issues of quality as well as representation of the Latvian tourism industry internationally. Assessing the international cooperation, all members agreed that in general international cooperation and unions bring positive impact, but not all of them saw tangible results and were not aware their exact benefits and the gains from the membership fees paid. Addressing the issue of support provided by associations to their members, the majority of respondents have received it in the areas of marketing, training, information provision and in the implementation of the EU projects. However, it has been noted that not everyone has asked for assistance or used it and there were opportunities for significant improvements in this area. On the issue of the main factors limiting the work of associations, human resources (appropriate persons on management boards and more active members, the lack of time) and funding (fees are quite high for smaller enterprises) were singled out. Many enterprises are also interested only in their own business or do not see the benefit of being a member of associations. In a few cases, specific requirements for members and competition among enterprises were also mentioned. Quality requirements, favourable taxation and visa issuing support policies, as well as the organisation of the international tourism fair BATLLTUR in Riga were pointed out as the main achievements of the national associations by their members. Addressing the issue of the future role of associations, the respondents provided mixed responses. Some argued that their role would increase while some others opposed this optimism, stressing however that their future would depend on their board.

Whereas during the interview with an official of the Ministry of Economy of Latvia responsible for tourism it was pointed out that the role of associations was to acts as intermediaries between the government and the industry since the majority of enterprises in tourism and hospitality were too small to defend themselves and their interests alone. Associations bring positive impact by helping the government understand the industry more clearly in terms of their needs and preferences. The positive impact of international cooperation was also mentioned as it provides a more global perspective of the situation in the industry. A good professional association should be willing to collaborate and listen to both: the government and companies. It is only in this way that the best solutions for all engaged parties could be found. The official thinks, that so far 
cooperation has been good, particularly if associations see the benefit of such cooperation for their interests. It is a two-way street and good relationships are highly important. Communication and information flow among the members of associations were mentioned as one of the main challenges, especially if there is more than one association in the same field. On some occasions, there has been a discrepancy between public messages and actual deeds. During the work process representatives of association might say one thing, but when issues become public suddenly they change their position. Looking ahead, it was stressed that the role of professional associations might grow as it becomes more prestigious for the public sector to work closely with the industry. In the case of Latvia, many regulations have been changed based on the initiative and pressure of professional associations. It shows that the influence is already quite strong and it might become even stronger in future.

The role of professional tourism associations in the development of the industry for the upcoming years is also characterised by the proposals of the Ministry of Economy developed in 2019 for the action plan 2020 - 2027 where professional associations as stakeholders have been included in the implementation of 18 (out of 93) activities and sub-activities, thus testifying of their role as important partners. The said activities can be grouped in the following directions: training of entrepreneurs and tourism education, cooperation and networking, the development of products and the overall market offer, the promotion of sales, resolution of labour issues, support for the implementation of new technologies and research (the Ministry of Economics of the Republic of Latvia, 2019), which largely overlap with research reflected in the overview of literature.

The forward-looking planning document has listed the future tasks of the associations for the development of sustainable tourism education, research and raising the qualification of employees occupied in the industry (7 out of 18 specific activities), including the organisation of training events, the engagement of professionals in the implementation of study programmes, participation in the campaign of the role of education in the tourism sector, the development of study programmes of various levels, the creation of content and in defining tourism research topics (the Ministry of Economics of the Republic of Latvia, 2019).

\section{Conclusions}

The following main conclusions can be drawn from the research results: Although on some issues the opinions of interviewees differ, all the respondents stress the positive role of national professional tourism organisations in the development of the tourism industry of Latvia. It proves that the key objective of 
associations is being achieved. The importance of the representation of specific interests of the industry, tangible input in the development of industryfavourable regulatory acts and implementation of support activities was particularly stressed. Although international cooperation is generally viewed positively, not all of the members have understood the gains it brings to the table. There are different opinions on cooperation between the top management of associations and regular members. Sometimes each side sees the deficiencies of others while ignoring one's own contribution. The practical assistance to members on issues like qualification and marketing are held in high regard by all parties. The creation of the feeling of community and exchange of experience is also valued highly. For the purpose of further improvement of the operation of associations, it is highly important to resolve the issue of insufficient internal communication, as well as to attract new members and more financing, which would allow to recruit paid employees and take away the burden on volunteers.

Speaking of the issue of the future of professional associations in Latvia, regardless of the negative opinions of some members, a majority of respondents believe that they will retain an important role. Therefore, the current situation in Latvia and the interests of all parties require strengthening of associations, including their merger.

\section{Acknowledgement}

The author of the article would like to thank Ms Yelaziveta Bulava for her outstanding contribution to the practical implementation of this research.

\section{References}

Association of Latvian professional guide [ALPG]. (2019). Retrieved from http://www.giduasociacija.lv/en/about-us/

Association of Latvian Travel Agents and Tour Operators [AHRL]. (2019). Retrieved from https://www.alta.net.lv/en/alta/alta-members

Candela, P.F. (2012). The Economics of Tourism Destinations. Springer.

Dickson, C., \& Arcodia, C. (2010). Promoting sustainable event practice: The role of professional associations. International Journal of Hospitality Management, 29, 236-244.

Gunn, C.A. (2002). Tourism Planning. Basics. Concepts. Cases. Routledge.

Helming, B., Ingerfurh S., \& Pinz, A. (2013). Success and Failure of Non-profit Organizations: Theoretical Foundations, Empirical Evidence, and Future Research. International Society for Third-Sector Research and the Johns Hopkins University, 25, 1514.

Hostelling Latvia, Latvian Youth Hostel Association [LYHA]. (2019). Retrieved from http://www.hostellinglatvia.com 
Vinklere, 2020. The Role of Professional Tourism Associations in Latvia

LATTURINFO. (2019). Retrieved from http://www.latturinfo.lv/images/dokumenti/biedri/ Latturinfo_biedri_2018.pdf

Latvian health tourism cluster [LHTC]. (2019). Retrieved from https://www.health travellatvia.lv/en/about-association

Latvijas Lauku tūrisma asociācija "Lauku celotajs" [LRTA]. (2019). Retrieved from https://www.celotajs.lv/lv/c/about/company

Latvijas muzeju biedrība [LMB]. (2019). Retrieved from http://www.muzeji.lv/lv/info/ about/lmb-biedru-saraksts/

Latvijas piḷu un muižu asociācija [LACPM]. (2019). Retrieved from https://pilis.lv/lv/parmums\#under-menu

Mason, P. (2008). Tourism impacts, planning and management. 2nd ed., Routledge.

Rhodri, T., \& Huw, T. (2013). `Hollow from the start'? Professional associations and the professionalization of tourism. The Service Industries Journal, 1-18. DOI:10.1080/02642069.2013.763346.

Saeima of the Republic of Latvia. (2003). Associations and Foundations Law.

The Ministry of Economics of the Republic of Latvia. (2019). Proposals for the 2020-2027 action plan for the development of Latvian tourism supply. Development of an action plan for the development of the Latvian tourism supply within the framework of the INTERREG Europe project BRANDtour (Priekšlikumi Latvijas tūrisma piedāvājuma attīstības rīcības plānam 2020-2027. Latvijas tūrisma piedāvājuma attīstības rīcības plāna izstrāde INTERREG Europe programmas projekta BRANDtour ietvaros).

UNEP \& UNWTO. (2005). Making Tourism More Sustainable. A Guide for Policy Makers. UNEP \& UNWTO, 11-12.

Veal, A.J. (2010). Leisure, Sport and Tourism, Politics, Policy and Planning. 3rd edition, Cab International. 